\title{
Effect of Dietary Fat on Rat Liver Microsomal Enzymes and Lipid Composition
}

\author{
Kommireddi NARAYANAREdDY,${ }^{\dagger}$ Adibhatla VAJRESWARI, ${ }^{*}$ and \\ Ramesh RAJPUROHIT ${ }^{\dagger \dagger}$ \\ National Institute of Nutrition, Indian Council of Medical Research, \\ Jamai Osmania P.O., Hyderabad-500 007, India
}

(Received December 22, 1991)

\begin{abstract}
Summary Dietary fat is known to influence the activities of various membrane-bound enzymes. The impact of various commonly consumed vegetable fats of India, viz., groundnut, coconut, safflower or mustard oil with varied fatty acid composition on the activities of liver microsomal membrane-bound enzymes and microsomal lipid composition was studied. In a feeding experiment, male weanling rats were fed these oils at $20 \mathrm{~g}$ per $100 \mathrm{~g}$ of the diet for 4 months. Liver microsomal cytochrome P-450 content was found to be significantly higher in the safflower oil-fed group and lowest in the coconut- and mustard oil-fed groups. The activity of UDP-glucuronyltransferase was highest in the mustard oil- and safflower oil-fed groups and lowest in the coconut oil-fed group and intermediary in the groundnut oil-fed group. The activity of $\mathrm{Mg}^{2+}$-ATPase was markedly lower in the safflower oil-fed group than in the rest of the groups. $\mathrm{Na}^{+}, \mathrm{K}^{+}$-ATPase activity was distinctly higher in the mustard oil-fed group, while $\mathrm{Mg}^{2+}$-ATPase activity was markedly higher in the groundnut oil-fed group. Further, the liver microsomes of safflower oil and mustard oil-fed groups showed higher amounts of cholesterol and phospholipids than the other two groups. However, the safflower oil group showed a higher cholesterol to phospholipid molar ratio than the other groups. Changes in cholesterol to phospholipid molar ratio as well as in fatty acid composition of the microsomal membranes could be responsible for the differences in the activities of the enzymes observed in the different groups.
\end{abstract}

Key Words: membrane-bound enzymes, cytochrome P-450, UDP-glucu-

*To whom correspondence should be addressed.

Present address: ${ }^{\dagger}$ Standard Research Centre, 7-1-27, Ameerpet, Hyderabad-500 016, India. ${ }^{\dagger \dagger}$ Fels Institute for Cancer Research \& Molecular Biology, Temple University School of Medicine, Philadelphia PA 19140. 
ronyltransferase, $\mathrm{Na}^{+}, \mathrm{K}^{+}$-ATPase, membrane lipids

Dietary fat is known to alter the activities of various membrane-bound enzymes of plasma membranes [1-4] as well as those of intracellular membranes such as mitochondrial and microsomal membranes [5-7] by altering their lipid milieu. Liver microsomes play an important role in drug-metabolizing enzymes. The cytochrome P-450-dependent, mixed-function oxidase system of liver microsomes is involved in the phase I reaction of a wide range of xenobiotics and of endogenous steroids such as cholesterol and steroid hormones [8]. Further, it is well documented that several nutritional factors modulate the activity of the mixed-function oxidase system. These mixed-function oxidases are membrane bound [9-11] and exhibit functional requirement for phosphatidylcholine, which is a structural lipid component of biomembranes. Phospholipids that contain mainly essential fatty acids are required for optimal activity of mixed-function oxidases $[12,13]$. Therefore, it is possible that variations in the fatty acid profiles of different dietary fats would alter the fatty acid composition of the membrane phospholipids, which might in turn modify the activity of mixed-function oxidases $[14,15]$. The scientific interest in this area has led to the emergence of several reports on the effect of the quality and quantity of dietary fat on the mixedfunction oxidase system $[16,17]$.

Further studies in this area have shown that dietary fat can also affect the activity of a phase II reaction enzyme, UDP-glucuronyltransferase (EC 2.4.1.17). However, there are no reports on the impact of various commonly consumed vegetable fats of India on the drug-metabolizing enzymes and other membranebound enzymes of liver microsomes. Therefore, in the present study an attempt was made to assess the influence of different dietary fats with varied fatty acid compositions on the activities of some of the membrane-bound enzymes and on the lipid microenvironment of the membrane.

\section{MATERIALS AND METHODS}

Weanling male CFY rats were distributed into 4 groups of 8 animals each and were fed groundnut, coconut, safflower or mustard oil at $20 \mathrm{~g}$ per $100 \mathrm{~g}$ of diet for 4 months. The composition of the experimental diet was based on AIN-76 $[18,19]$ and is shown in Table 1. Fatty acid composition of the dietary fats is given in Table 2. Coconut oil is rich in saturated fatty acids, safflower oil has a high amount of linoleic acid $(18: 2)$, mustard oil has a high content of erucic acid (22: $1)$, and groundnut oil has a fairly good proportion of oleic (18:1) and linoleic $(18: 2)$ acids. At the end of experimental feeding, the animals were killed by cervical dislocation. Livers were dissected out and liver microsomes were prepared by differential centrifugation as described earlier [20]. Protein was determined by the method of Lowry et al. [21] using crystalline serum albumin as standard. 
Table 1. Diet composition.

\begin{tabular}{lc}
\hline Ingredient & Diet composition $(\mathrm{g} / 100 \mathrm{~g}$ diet $)$ \\
\hline Casein & 20.00 \\
DL-Methionine & 0.30 \\
Cellulose & 5.00 \\
Oil & 20.00 \\
Mineral mixture & $4.00^{*}$ \\
Vitamin mixture & $0.10^{* *}$ \\
Choline chloride & 0.20 \\
Starch & 50.40 \\
\hline
\end{tabular}

Diet was prepared as per AIN standards for nutrients. *USP XVII. **AIN Standard.

Table 2. Fatty acid composition of oils.*

\begin{tabular}{ccccc}
\hline Fatty acids & Coconut oil & Mustard oil & Groundnut oil & Safflower oil \\
\hline $8: 0$ & 4.4 & - & - & - \\
$10: 0$ & 6.8 & - & - & - \\
$12: 0$ & 36.7 & - & - & - \\
$14: 0$ & 26.5 & - & - & 0.1 \\
$16: 0$ & 10.5 & 2.2 & 12.3 & 2.9 \\
$18: 0$ & 3.1 & 1.3 & 4.2 & 2.1 \\
$18: 1$ & 9.0 & 10.4 & 38.6 & 15.6 \\
$18: 2$ & 3.0 & 15.3 & 38.1 & 79.4 \\
$18: 3$ & - & 14.3 & 2.2 & - \\
$20: 0$ & - & - & 1.8 & - \\
$20: 1$ & - & 3.0 & - & - \\
$22: 0$ & - & - & 2.8 & - \\
$22: 1$ & - & 53.4 & - & - \\
\hline
\end{tabular}

${ }^{*}$ Expressed as \% distribution of fatty acids. -, not detectable.

Cytochrome P-450 was measured according to the method of Omura and Sato [22], which is based on the principle that the reduced form of cytochrome P-450 readily combines with carbon monoxide to form a complex having an absorption maximum at $450 \mathrm{~nm}$ when read against its reduced form not treated with carbon monoxide. The difference in absorption at $450 \mathrm{~nm}$ from that at $490 \mathrm{~nm}$ was used for calculating the cytochrome P-450 content.

UDP-glucuronyltransferase activity was assayed according to the method of Woodcock and Wood [23]. The assay was performed in a medium containing 0.1 M phosphate buffer ( $\mathrm{pH} 7.4$ ), $5 \mathrm{mM} \mathrm{MgCl}_{2}, 0.2 \mathrm{mM}$-nitrophenol, $2.5 \mathrm{~mm}$ UDPglucuronic acid, and $1 \mathrm{mg}$ microsomal protein in a final volume of $0.4 \mathrm{ml}$. UDP-glucuronic acid was omitted from all blanks. The reaction was arrested by the addition of an equal volume of $0.2 \mathrm{M}$ trichloroacetic acid (TCA). The tubes were centrifuged, and a $0.5-\mathrm{ml}$ aliquot of supernatant was added to $1.5 \mathrm{ml}$ of 0.5 м $\mathrm{NaOH}$. The $p$-nitrophenol concentration was monitored at $405 \mathrm{~nm}$ in a Gilford spectrophotometer (Gilford Instrument Laboratories Inc., $\mathrm{OH}$ ). The reaction was found to be linear up to $20 \mathrm{~min}$ and $2 \mathrm{mg}$ enzyme protein under these conditions. $\mathrm{Na}^{+}, \mathrm{K}^{+}$-ATPase and $\mathrm{Mg}^{2+}$-ATPase activities of liver microsomal membranes were Vol. 12, No. 3, 1992 
assayed according to the method of Post and Sen [24] with a slight modification. Ouabain when required was added at a $1 \mathrm{~mm}$ concentration. The reaction mixture contained $140 \mathrm{~mm} \mathrm{NaCl}, 14 \mathrm{~mm} \mathrm{KCl}, 1 \mathrm{~mm}$ EGTA, $3 \mathrm{~mm} \mathrm{MgCl}_{2}, 3 \mathrm{~mm}$ Tris-ATP, and $50 \mu \mathrm{g}$ enzyme protein in a final volume of $0.5 \mathrm{ml}$. The reaction was started by the addition of Tris-ATP and arrested by that of $0.5 \mathrm{ml}$ of ice-cold $10 \%$ TCA. $\mathrm{Na}^{+}$, $\mathrm{K}^{+}$-ATPase activity was taken as the difference between the activities obtained in the presence and absence of ouabain in the reaction medium. The activity obtained in the presence of $1 \mathrm{~mm}$ ouabain was taken as the $\mathrm{Mg}^{2+}$-ATPase activity.

Lipids were extracted from liver microsomes according to the method of Folch et al. [25]. Total cholesterol and phospholipid contents were determined as described by Zlatkis et al. [26] and Bartlett [27], respectively.

Statistical evaluation was done by analysis of variance.

\section{RESULTS}

Effects of dietary groundnut, coconut, safflower or mustard oil on the body and liver weights of rats and on liver microsomal cytochrome P-450 content are shown in Table 3 . The body weight of the mustard oil-fed group was significantly lower than that of the other groups. However, the liver weight as well as the

Table 3. Body weight, liver weight, and liver cytochrome P-450 content of rats fed various oil diets.

\begin{tabular}{|c|c|c|c|c|}
\hline & Coconut oil & Mustard oil & Groundnut oil & Safflower oil \\
\hline Body weight $(\mathrm{g})$ & $484.9 \pm 8.86^{\mathrm{a}, \mathrm{c}}$ & $335.5 \pm 10.85^{b}$ & $496.3 \pm 1.24^{\mathrm{a}}$ & $462.9 \pm 12.33^{b}$ \\
\hline Liver weight $(\mathrm{g})$ & $13.6 \pm 0.50^{\mathrm{a}}$ & $15.3 \pm 0.36^{\mathrm{b}}$ & $13.8 \pm 0.31^{\mathrm{a}}$ & $13.0 \pm 0.42^{\mathrm{a}}$ \\
\hline $\begin{array}{l}\text { Liver weight (as \% of body } \\
\text { weight) }\end{array}$ & $2.82 \pm 0.11^{\mathrm{a}}$ & $4.59 \pm 0.17^{\mathrm{b}}$ & $2.79 \pm 0.09^{\mathrm{a}}$ & $2.83 \pm 0.11^{\mathrm{a}}$ \\
\hline $\begin{array}{l}\text { Cytochrome P-450 content } \\
\text { (nmol/mg protein) }\end{array}$ & $0.63 \pm 0.06^{\mathrm{a}}$ & $0.61 \pm 0.03^{\mathrm{a}}$ & $0.79 \pm 0.05^{\mathrm{b}}$ & $0.97 \pm 0.06^{\mathrm{c}}$ \\
\hline
\end{tabular}

Values are Mean \pm SE, $n=8$ observations in each group. Values in the horizontal rows not showing a common superscript are significantly different from each other at the $5 \%$ level $(p<0.05)$ by analysis of variance.

Table 4. Enzyme activities in liver microsomal membranes from rats fed different oil diets.

\begin{tabular}{ccccc}
\hline & Coconut oil & Mustard oil & Groundnut oil & Safflower oil \\
\hline $\mathrm{Na}^{+}, \mathrm{K}^{+}-\mathrm{ATPase}$ & $0.38 \pm 0.05^{\mathrm{a}}$ & $0.81 \pm 0.13^{\mathrm{b}}$ & $0.36 \pm 0.08^{\mathrm{a}}$ & $0.21 \pm 0.06^{\mathrm{a}}$ \\
$(\mu \mathrm{mol} \mathrm{Pi} / \mathrm{mg}$ protein/h) & $(6)$ & $(7)$ & $(7)$ & $(5)$ \\
$\mathrm{Mg}^{2+}-\mathrm{ATPase}$ & $3.27 \pm 0.18^{\mathrm{a}}$ & $3.23 \pm 0.16^{\mathrm{a}}$ & $4.28 \pm 0.17^{\mathrm{b}}$ & $2.55 \pm 0.13^{\mathrm{c}}$ \\
$\quad(\mu$ mol Pi/mg protein/h) & $(6)$ & $(7)$ & $(7)$ & $(5)$ \\
$\begin{array}{c}\text { UDP-glucuronyltransferase } \\
\text { (nmol conjugated/min/ }\end{array}$ & $0.49 \pm 0.05^{\mathrm{a}}$ & $1.01 \pm 0.16^{\mathrm{b}}$ & $0.65 \pm 0.13^{\mathrm{a}}$ & $1.00 \pm 0.13^{\mathrm{b}}$ \\
mg protein) & $(4)$ & $(8)$ & $(7)$ & $(8)$ \\
\hline
\end{tabular}

Values are Mean \pm SE. Numbers in parentheses indicate the number of observations. Values in horizontal rows not sharing the common superscript are significantly different from each other at the $5 \%$ level $(p<0.05)$ by analysis of variance. 
DIETARY FAT AND LIVER MICROSOMAL ENZYMES AND LIPIDS

Table 5. Lipid composition of liver microsomal preparations.

\begin{tabular}{lcccc}
\hline & Coconut oil & Mustard oil & Groundnut oil & Safflower oil \\
\hline $\begin{array}{l}\text { Cholesterol } \\
(\mu \mathrm{mol} / \mathrm{mg} \text { protein })\end{array}$ & $0.14 \pm 0.01^{\mathrm{a}}$ & $0.29 \pm 0.01^{\mathrm{b}}$ & $0.20 \pm 0.01^{\mathrm{c}}$ & $0.26 \pm 0.03^{\mathrm{c}}$ \\
$\begin{array}{c}\text { Phospholipid } \\
\quad(\mu \mathrm{mol} / \mathrm{mg} \text { protein })\end{array}$ & $0.19 \pm 0.01^{\mathrm{a}}$ & $0.38 \pm 0.01^{\mathrm{b}}$ & $0.23 \pm 0.01^{\mathrm{c}}$ & $0.30 \pm 0.05^{\mathrm{c}}$ \\
$\begin{array}{c}\text { Cholesterol/phospholipid } \\
\text { molar ratio }\end{array}$ & $0.74 \pm 0.04^{\mathrm{a}}$ & $0.76 \pm 0.02^{\mathrm{a}}$ & $0.86 \pm 0.04^{\mathrm{a}, \mathrm{b}}$ & $0.89 \pm 0.06^{\mathrm{b}}$ \\
\hline
\end{tabular}

Values are Mean \pm SE. $n=6$ observations in each group. Values in the horizontal rows not sharing a common superscript are significantly different from each other at the $5 \%$ level $(p<0.05)$ by analysis of variance.

proportion of liver weight to body weight were markedly higher in this group. The results on the activities of $\mathrm{Na}^{+}, \mathrm{K}^{+}$-ATPase, $\mathrm{Mg}^{2+}$-ATPase, and UDP-glucuronyltransferase are presented in Table 4. Mustard and safflower oil feeding resulted in enhanced UDP-glucuronyltransferase activity as compared with feeding with groundnut and coconut oils. The activity of $\mathrm{Mg}^{2+}$-ATPase was markedly lower in the safflower oil-fed group than in the rest of the groups. $\mathrm{Na}^{+}, \mathrm{K}^{+}$-ATPase activity was distinctly higher in the mustard oil-fed group. The results on the lipid composition of liver microsomes from the various groups are presented in Table 5. Total cholesterol and phospholipid contents were significantly higher in safflower oil- and mustard oil-fed groups. However, safflower oil feeding alone resulted in an enhanced molar ratio of cholesterol to phospholipid.

\section{DISCUSSION}

The results of the present study indicate that feeding of mustard oil caused a significant growth depression compared with groundnut, coconut or safflower oil feeding, which can be attributed to the presence of erucic $(22: 1)$ acid in the mustard oil [28]. Further, the liver weight and liver weight as a percentage of body weight were significantly higher in this group, probably due to lipid infiltration.

Changes in the lipid composition of microsomal membrane are known to affect the structure and dynamics of the bilayer and to produce diverse effects on the kinetic behavior of intrinsic proteins of the membrane [29-34]. The influence of quality and quantity of dietary fat on mixed-function oxidases has been studied extensively [35-40]. Further, the direct relationship between the dietary content of linoleic, linolenic, eicosapentaenoic, and docosahexaenoic acids and cytochrome P-450 content of liver microsomal membranes has been well documented [17, 38]. The present study also confirms some of these earlier observations. The diet containing safflower oil (rich in linoleic $(18: 2)$ acid) showed the highest level of cytochrome P-450 followed by groundnut oil having the next highest level of linoleic (18:2) acid. Mustard and coconut oil diets had the lowest level of cytochrome P-450 content. A previous study on a high erucic acid-containing rapeseed oil diet indicated no effect on liver microsomal cytochrome P-450 content 
[41], and the present study corroborates this earlier observation.

Although in the present study the liver microsomes were not analyzed for fatty acid composition, our own studies on fatty acid profiles of membrane preparations from other sources such as erythrocytes and cardiac tissue [42, 43] and those of others [5-7] suggest that the fatty acid composition of membranes does reflect that of the dietary fat. Based on such observations changes in the fatty acid composition could be envisaged even with respect to liver microsomal membranes. In fact, Caster et al. [44] demonstrated a relationship between the fatty acid composition of the diet and that of hepatic tissue.

The data on lipid composition of the liver microsomal membranes indicate that feeding of highly unsaturated fats such as safflower and mustard oils results in high absolute amounts of cholesterol and phospholipids. Similar observations were made by us with respect to the erythrocyte membrane preparation of these dietary groups [42]. A similar increase in cholesterol content of liver microsomes of safflower oil-fed rats was reported by Lee et al. [45]. This observed increase in cholesterol content could be a compensatory mechanism to maintain optimal fluidity of liver microsomal membranes in the event of increased levels of unsaturated fatty acid-containing phospholipid.

UDP-glucuronyltransferases are a group of enzymes of the endoplasmic reticulum responsible for the phase II step of bio-transformation of drugs, xenobiotics, and endogenous substrates [46]. These are phospholipid-dependent integral proteins of the membrane, with their activity depending on the interaction with lipids containing phosphoryl groups [47, 48]. The kinetic properties of UDPglucuronyltransferase in liver microsomes of the guinea pig have been studied extensively $[20,32,33]$. Essential fatty acid deficiency induced a reduction in the double-bond index of liver microsomal lipids of the guinea pig and resulted in depressed UDP-glucuronyltransferase activity without altering the cholesterol to phospholipid molar ratio [20]. On the other hand, the altered UDP-glucuronyltransferase activity due to cholesterol supplementation has been attributed to a higher membrane ordering effect produced by cholesterol that could not be offset by a decreased phosphatidylethanolamine to phosphatidylcholine ratio [32].

In the present study feeding of highly unsaturated fats such as safflower and mustard oil resulted in higher UDP-glucuronyltransferase activity, thereby suggesting that it is the total unsaturated fatty acid content of the oil rather than the polyunsaturated fatty acid fraction that is responsible for the stimulation of this drug-metabolizing enzyme that occurs by alteration of the lipid milieu of the membrane. The early work of Mounie et al. [49] suggested that the vegetable fats, viz., coconut oil-, groundnut oil-, and corn oil-containing diets, had no effect on liver microsomal cytochrome P-450 content. However, corn oil and fish oil diets have been shown to stimulate UDP-glucuronyltransferase activity with substrates such as 4-nitrophenol and 2-naphthol 4 methyl umbelliferone (group I substrates), which activity is considered to be an indicator of hepatotoxicity [50]. A similar increase in the activity of UDP-glucuronyltransferase with 4-nitrophenol was 
observed in safflower oil- and mustard oil-fed rat liver microsomes in the present study, which is suggestive of the potential hepatotoxic nature of these oils. Enhanced glucose-6-phosphatase activity due to feeding with high erucic acidcontaining rapeseed oil, which is yet another indicator of hepatotoxicity, was also reported earlier [41]. Thus the results of the present study along with the earlier observations [41] substantiate the potential hepatotoxic nature of high erucic acid-containing oils.

The effect of dietary fat on other membrane-bound enzymes such as adenylate cyclase and 5'-nucleotidase of the plasma membrane of various tissues such as cardiac tissue has been reported [1-3]. There are also reports on the influence of dietary fat on liver microsomal fatty acid synthetase, desaturase, and $\mathrm{Ca}^{2+}$-ATPase [51-53]. Nutritional manipulations that induce higher saturation of membrane fatty acyl chains result in higher desaturase activity [54]. However, $\mathrm{Ca}^{2+}$-transport ATPase and $\mathrm{Ca}^{2+}$-uptake in liver microsomes were significantly depressed in essential fatty acid-deficient animals [53]. These effects have been attributed mainly to changes in fatty acid composition rather than to altered contents of membrane cholesterol and phospholipids [53]. However, to our knowledge there are no reports describing the possible effects of dietary fat on other ion-transporting enzymes of liver microsomes.

Our results on microsomal membrane ATPase suggest that feeding with safflower oil, which is rich in polyunsaturated fatty acids, has as depressing effect on both $\mathrm{Na}^{+}, \mathrm{K}^{+}$-ATPase and $\mathrm{Mg}^{2+}$-ATPase, whereas mustard oil (rich in erucic acid) feeding enhanced the activity of these two enzymes. Similar observation was made by us on the activities of these enzymes in the erythrocyte membrane of rats in response to feeding with safflower and mustard oil diets [42]. The depressed $\mathrm{Na}^{+}, \mathrm{K}^{+}$-ATPase and $\mathrm{Mg}^{2+}$-ATPase activities of safflower oil-fed animals is due to higher polyunsaturated fatty acid content of this oil, since higher levels of PUFA are known to inhibit $\mathrm{Na}^{+}, \mathrm{K}^{+}$-ATPase activity [1]. This contention was further substantiated by the observations that essential fatty acid-deficient diet enhanced the $\mathrm{Na}^{+}, \mathrm{K}^{+}$-ATPase activity of kidney, submaxillary gland, heart and liver plasma membranes $[1,55,56]$. The present study, in addition to establishing the inhibitory effect of increased polyunsaturated fatty acid content on some membranebound enzymes such as $\mathrm{Na}^{+}, \mathrm{K}^{+}$-ATPase and $\mathrm{Mg}^{2+}$-ATPase [1], also suggests a stimulatory effect of highly unsaturated fats on some of the drug-metabolizing enzymes.

We can conclude from the present study that the activities of various membrane-bound enzymes of liver microsomes are influenced by the quality of the dietary fat, which in turn alters the lipid microenvironment of these enzymes.

We are grateful to Dr. B.S. Narasinga Rao, former Director, and Dr. Vinodini Reddy, Director of the National Institute of Nutrition, Hyderabad, for their keen interest in this study. We are thankful to the staff of LAISC, Hyderabad, for the timely supply of weanling rats. Thanks are also due to Dr. K. Visweswara Rao for his advice on the statistical analysis and Dr. M.S. 
Bamji for critical evaluation of the manuscript. We appreciate the technical assistance of Mr. G.L. Nageswara Rao in the laboratory and that of Mr. Armugam in the maintenance of the animals.

\section{REFERENCES}

1. Brivio-Haugland, R.P., Louis, S.L., Musch, K., Waldeck, N., and Williams, M.A. (1976): Liver plasma membranes from essential fatty acid-deficient rats. Isolation, fatty acid composition and activities of $5^{\prime}$-nucleotidase, ATPase and adenylate cyclase. Biochim. Biophys. Acta, 433, 150-163.

2. Awad, A.B., and Chattopadhyay, J.P. (1983): Effect of dietary fats on lipid composition and enzyme activities of rat cardiac sarcolemma. $J$. Nutr., 113, 1878-1884.

3. Colard, O., Kervabon, A., and Roy, C. (1980): Effects on adenylate cyclase activities of unsaturated fatty acid incorporation into rat liver plasma membrane phospholipids. Specific modulation by linoleate. Biochem. Biophys. Res. Commun., 95, 97-102.

4. Alam, S.Q., and Alam, B.S. (1986): Effect of essential fatty acid deficiency on acyl group composition, membrane fluidity and adenylate cyclase activity in plasma membranes of rat submandibular salivary glands. $J$. Nutr., 116, 1620-1630.

5. Barzanti, V., Biagi, P.L., Maranesi, M., and Turchetto, E. (1986): Effect of lipids having different n-6 and n-3 fatty acid contents on some organs and subcellular structures of the rat. Prog. Lipid Res., 25, 221-224.

6. Clandinin, M.T. (1978): The role of dietary long chain fatty acids in mitochondrial structure and function. Effects on rat cardiac mitochondrial respiration. J. Nutr., 108, 273-281.

7. Innis, S.M., and Clandinin, M.T. (1981): Dynamic modulation of mitochondrial inner membrane lipids in rat heart by dietary fat. Biochem. J., 193, 155-167.

8. Cooper, D.Y., Levin, S., Narasimhulu, S., Rosenthal, O., and Estabrook, R.W. (1965): Photochemical action spectrum of terminal oxidase of mixed function oxidase system. Science, 147, 400-402.

9. Miller, O.W. (1976): Nutrition and drug metabolism. Introduction. Fed. Proc., 35, 2459.

10. Anderson, K.E., Conney, A.H., and Kappas, A. (1982): Nutritional influences on chemical biotransformation in humans. Nutr. Rev., 40, 161-171.

11. Young, C.S., and Yoo, J.S.H. (1988): Dietary effects on drug metabolism by the mixed function oxidase system. Pharmacol. Ther., 38, 53-72.

12. Young, C.S. (1977): Mini review: The organization and interaction of monooxygenase enzymes in the microsomal membrane. Life Sci., 21, 1047-1058.

13. Lu, A.Y. (1976): Liver microsomal drug-metabolizing enzyme system: Functional components and their properties. Fed. Proc., 35, 2460-2463.

14. Wade, A.E. (1986): Effects of dietary fat on drug metabolism. J. Environ. Pathol. Toxicol. Oncol., 6, 161-189.

15. Laitinen, M., Hietanen, E., Varinio, H., and Hannien, O. (1975): Dietary fats and properties of endoplasmic reticulum I. Dietary lipid induced changes in composition of microsomal membranes in liver and gastroduodenal mucosa of rat. Lipids, 10, 461-466.

16. Wade, A.E., White, R.A., Walton, L.C., and Bellows, J.T. (1986): Dietary fat--a requirement for induction of mixed function oxidase activities in starved, refed rats. Biochem. Pharmacol., 34, 3747-3754.

17. Saito, M., Oh-Hash, A., Kubota, M., Nishide, E., and Yamaguchi, M. (1990): Mixed function oxidases in response to different types of dietary lipids in rats. Br. J. Nutr., 63, 249257.

18. American Institute of Nutrition (1977): Report of the American Institute of Nutrition ad hoc committee on standards for nutritional studies. J. Nutr., 107, 1340-1348.

19. American Institute of Nutrition (1980): Second report of the ad hoc committee on standards for nutritional studies. J. Nutr., 110, 1726.

20. Castuma, C.E., and Brenner, R.R. (1983): Effect of fatty acid deficiency on microsomal membrane fluidity and cooperativity of UDP-glucuronyltransferase. Biochim. Biophys. 
Acta, 729, 9-16.

21. Lowry, O.H., Rosebrough, N.J., Farr, A.L., and Randall, R.J. (1951): Protein measurement with the folin-phenol reagent. J. Biol. Chem., 193, 265-275.

22. Omura, T., and Sato, R. (1964): The carbon monoxide binding pigment of liver microsomes. J. Biol. Chem., 239, 2370-2378.

23. Woodcock, B.G., and Wood, G.C. (1971): Effect of protein-free diet on UDP-glucuronyltransferase and sulphotransferase activities in rat liver. Biochem. Pharmacol, 20, 2703-2713.

24. Post, R.L., and Sen, A.K. (1967): Sodium potassium stimulated ATPase, in Methods in Enzymology, Vol. 10, ed. by Colowick, S.P. and Kaplan, N.O., Academic Press, New York, pp. 762-768.

25. Folch, J., Lees, M., and Sloane-Stanley, G.H. (1957): A simple method for the isolation and purification of total lipids from animal tissues. J. Biol. Chem., 226, 497-509.

26. Zlatkis, A., Zak, B., and Boyle, A.J. (1953): A new method for the direct determination of serum cholesterol. J. Lab. Clin. Med., 41, 486-492.

27. Bartlett, G.R. (1959): Phosphorus assay in column chromatography. J. Biol. Chem., 234, 466-468.

28. Beare-Rogers, J.L. (1977): Docosanoic acids in dietary fats. Prog. Chem. Fats Other Lipids, 15, 29-56.

29. Brenner, R.R. (1984): Effect of unsaturated fatty acids on membrane structure and enzyme kinetics. Prog. Lipid Res., 23, 69-96.

30. Brenner, R.R., Castuma, C.E., and Garder, H. (1986): Possible mechanisms by which microsomal lipid bilayer composition modify bound enzyme kinetics. Prog. Lipid Res., 25, 47-52.

31. Vessey, D.A., and Zakim, D. (1972): Regulation of microsomal enzymes by phospholipids. V. Kinetic studies of hepatic uridinediphosphate glucuronyltransferase. J. Biol. Chem., 247, 3023-3028.

32. Castuma, C.E., and Brenner, R.R. (1986): Effect of dietary cholesterol on microsomal membrane composition dynamics and kinetic properties of UDP-glucuronyltransferase. Biochim. Biophys. Acta, 855, 231-242.

33. Castuma, C.E., and Brenner, R.R. (1986): Cholesterol dependent modification of microsomal dynamics and UDP-glucuronyltransferase dynamics. Biochemistry, 25, 4733-4738.

34. Castuma, C.E., and Brenner, R.R. (1989): The influence of fatty acid unsaturation and physical properties of membrane phospholipids on UDP-glucuronyltransferase activity. Biochem. J., 258, 723-731.

35. Kaschnitz, R. (1970): Aryl 4-hydroxylase cytochrome P-450 and microsomal lipids on essential fatty acid deficiency. Hoppe Seylers Z. Physiol. Chem., 351, 771-774.

36. Century, B. (1973): A role of dietary lipid in the ability of phenobarbital to stimulate drug detoxification. J. Pharmacol. Exp. Ther., 185, 185-194.

37. Wade, A.E., and Norred, W.P. (1976): Effect of dietary lipid on drug metabolizing enzymes. Fed. Proc., 35, 2475-2479.

38. Hammer, C.T., and Wills, E.D. (1979): The effect of dietary fats on the composition of liver endoplasmic reticulum and oxidative drug metabolism. Br. J. Nutr., 41, 465-475.

39. Clinton, S.K., Mulloy, A.L., and Visek, W.J. (1984): Effects of dietary lipid saturation on prolactin secretion, carcinogen metabolism and mammary carcinogenesis in rats. $J$. Nutr., 114, 1630-1639.

40. Wade, A.E., Wu, B., and Caster, W.O. (1972): Relationship of dietary essential fatty acid composition to hepatic drug hydroxylation. Pharmacology, 7, 305-314.

41. Collomb, M.H., Albrecht, R., Griffaton, G., Manchon, P., and Lowry, R. (1974): Activity of microsomal enzymes in the livers of rats fed rapeseed oil. Enzyme, 18, 300-309.

42. Vajreswari, A., and Narayanareddy, K. (1992): Effect of dietary fats on erythrocyte membrane lipid composition and membrane-bound enzyme activities. Metabolism, 41, 352-358.

43. Vajreswari, A., and Narayanareddy, K. (1992): Effect of dietary fats on some membrane bound enzymes, lipids and fatty acid composition of rat heart sarcolemma. Lipids, 27 (in

Vol. 12, No. 3, 1992 
press).

44. Caster, W.O., Andrew, J.W., Jr., Moh-hauer, H., and Holman, R.T. (1976): Effect of essential and non-essential fatty acids in complex mixture of fatty acid mixture on fatty acid composition of liver lipids. J. Nutr., 105, 1809-1816.

45. Lee, J.H., Sugano, M., and Ide, T. (1988): Effects of various combinations of w-3 and w-6 polyunsaturated fats with saturated fat on serum lipid levels and eicosanoid production in rats. J. Nutr. Sci. Vitaminol, 34, 117-129.

46. Bock, K.W., Josting, D., Lilienblum, W., and Pfeil, H. (1978): Purification of rat liver microsomal UDP-glucuronyltransferase, separation of two enzyme forms inducible by 3 methyl cholanthrene or phenobarbital. Eur. J. Biochem., 98, 19-26.

47. Erickson, R.H., Zakim, D., and Vessey, D.A. (1978): Preparation and properties of a phospholipid free form of microsomal UDP-glucuronyltransferase. Biochemistry, 17, 37063711 .

48. Singh, O.M., Graham, A.B., and Wood, G.C. (1981): Phospholipid dependence of UDPglucuronyltransferase. Purification, delipidation and reconstitution of microsomal enzyme from guinea pig liver. Eur. J. Biochem., 116, 311-316.

49. Mounie, J., Faye, B., Magdlon, J., Goudonnet, H., Truchot, R., and Siest, G. (1986): Modulation of UDP-glucuronyltransferase activity in rats by dietary lipids. $J$. Nutr., 116, 2034-2043.

50. Pfeil, H., and Bock, K.W. (1983): Electro-immunochemical quantification of UDPglucuronyltransferase in rat liver microsomes. Eur. J. Biochem., 131, 619-623.

51. Garg, M.L., Sebokova, E., Thomson, A.B.R., and Clandinin, M.T. (1988): $\Delta^{6}$-Desaturase activity in liver microsomes of rats fed diets enriched with cholesterol and/or (W-3) fatty acids. Biochem. J., 249, 351-356.

52. Garg, M.L., Thomson, A.B.R., and Clandinin, M.T. (1988): Effect of dietary cholesterol and/or w-3 fatty acids on lipid composition and $\Delta^{5}$-desaturase activity of rat liver microsomes. J. Nutr., 118, 661-668.

53. Christon, R., Fernandez, Y., Canbon Gos, C., Periquet, A., Deltour, P., Leger, C.L., and Mitjavila, S. (1988): The effect of dietary essential fatty acid deficiency on the composition and properties of liver microsomal membrane of rats. J. Nutr., 118, 1311-1318.

54. Brenner, R.R., Garda, H., De Gomez Dumm, I.N.T., and Pezzano, H. (1981): Early effects of EFA deficiency on structure and enzymatic activity of rat liver microsomes. Prog. Lipid Res., 20, 315-321.

55. Alam, S.Q., and Alam, B.S. (1983): Acyl group composition of lipids and the activities $\left(\mathrm{Na}^{+}+\mathrm{K}^{+}\right)$-ATPase 5 -nucleotidase and $\gamma$-glutamyltransferase in salivary glands and kidneys of rats fed different dietary fats. Biochim. Biophys. Acta, 758, 1-9.

56. Alam, S.Q., Alam, B.S., and Ren, Y.F. (1987): Adenylate cyclase activity, membrane fluidity and fatty acid composition of rat heart in essential fatty acid deficiency. J. Mol. Cell. Cardiol., 19, 465-475. 